\title{
Discussion on the Second Classroom Construction of Applied Agricultural College
}

\author{
Yiming Liu* \\ College of Engineering and Technology \\ Tianjin Agricultural University \\ Tianjin, China \\ 421334362@qq.com \\ Hua Liu \\ College of Engineering and Technology \\ Tianjin Agricultural University \\ Tianjin, China \\ 41599386@qq.com
}

\author{
Yu Shi \\ College of Engineering and Technology \\ Tianjin Agricultural University \\ Tianjin, China \\ 95462845@qq.com \\ Yun Han \\ College of Engineering and Technology \\ Tianjin Agricultural University \\ Tianjin, China \\ 396051786@qq.com
}

\begin{abstract}
This paper investigates how to establish an efficient complementary education system of second classroom, in applied agricultural colleges. By analyzing the achievements and challenges in the second classroom of a well-known applied agricultural college, we propose methods to optimize the construction of the second classroom. First, agricultural colleges can highlight its specialty in agricultural science on a student oriented basis, especially its spirit in promoting rural development and urbanization. Second, they can implement the credit system curriculum system, credit management system, as well as the instructor evaluation and incentive system. In addition, the use of new media platforms and other new technology will also help to increase the participation and effectiveness of the second classroom activities.
\end{abstract}

Keywords-Applied agricultural universities; Second classroom; Agricultural characteristics; Optimization measures

\section{THE SIGNIFICANCE OF BUILDING A SECOND CLASSROOM AT A UNIVERSITY}

The second class is a general term for activities that are carried out in order to enrich students' after-class life and improve their overall quality [1]. Expanding and deepening the second class is being the objective condition to develop students' innovative capabilities in the operational system of college students' quality cultivation, and the important stage to cultivate and improve students' innovation and quality. Compared with classroom teaching, the second classroom is flexible, diverse and with strong interaction. It emphasizes that students should combine theory with practice, apply their knowledge, experience life and society, exercise ability, and contribute to student personality in the process of practice [2].

For the applied agricultural colleges and universities with the goal of "cultivating high-quality applied talents with the characteristics of "three rural" and serving the agricultural development in the region", the second class is an important way of develop practical teaching, cultivate spirit of innovation and feeling of "agriculture, rural areas and farmers".

\section{THE ANALYSIS OF STATUS AND PROBLEMS FOR THE SECOND CLASSROOM}

For a long time, for lack of understanding, the second classroom is usually used to carry out quality education activities that beyond professional education, while its professional and practical role is weakened. There are mainly the following problems:

\section{A. Low Student Participation}

The main participants of the second classroom activity are the school committee, academic work office, and counselors of various teaching units. The participants are mostly confined to student leaders and social activity activists, while the students with poor initiative and low motivation are involved less. In addition, most of the participants in the second classroom activity are freshman and sophomore. Most of the senior students are busy with professional learning and employment, and rarely participate in second classroom activities. The reason is that the orientation of the second class is too one-sided. Its main purpose is to enrich students' after-school life, and it lacks integration with professional knowledge and guidance of professional teachers, and so it is not attractive to students.

\section{B. Low Academic Content}

The contents of the second class are mostly concentrated on student activities such as social investigation activities, cultural activities, art evenings, work-study programs, speech debates, etc., and lack of connection with professional knowledge learning. The functions are severely narrowed. From the perspective of talent cultivation, the content design of the second classroom is out of line with the talent cultivation system, which has led to utilitarian and entertainment trends in the development of activities. 


\section{Lack of Attention and Guidance}

The lack of understanding of the role of the second classroom education and teaching work led many colleges and universities to pay more attention to the teaching needs of the first classroom in the process of campus planning, teaching facilities and other hardware construction arrangements, which makes the second classroom in a marginal state in universities' policy formulation, funding, staffing, and facilities improvement. That leads to a lack of rich content, a low level, and a lack of systematic in the second classroom, which Difficult to play its role.

Moreover, because the second classroom at this stage lacks the attention and guidance given to the leadership level, teachers are reluctant to spend time guiding, and that make students lose their enthusiasm for participating in activities. The purpose of the design of the event cannot achieve the purpose of the second classroom construction. Therefore, the purpose of the second classroom construction is also difficult to reach.

\section{Measures to Optimize the SECONd Classroom CONSTRUCTION}

According to the problems existed in the second classroom of colleges, and the training objectives and subject characteristics of the applied agricultural colleges and universities, this paper proposed some measures to optimize the second classroom.

\section{A. Working on Student-oriented Basis}

The second classroom activity should be guided by the interests of students, so that most students can choose the projects they enjoy. By doing this, students' enthusiasm for participation can be greatly stimulated [3-4]. At the school level, it is possible to develop quality activities that demonstrate the universities' spirit and educational concept. At the faculty level, the professional training program should be taken into consideration. The second classroom activity should be designed from the perspective of talent cultivation and practical teaching, and organized in stages according to the grade level.

\section{B. Give Full Play to Agricultural Specialties}

The development of the second classroom in agricultural colleges and universities should be based on the characteristics of agricultural specialties. A long-term mechanism for educating in high-quality applied talents with the characteristics of "agriculture, countryside and farmers" should be formed [5]. In order to cultivate students' professional learning abilities and interests, and improve their application and professional abilities, faculties can organize and implement them in accordance with professional characteristics, organizing a series of social practice activities to serve the "three rural issues". Through the implementation of a series of second classroom activities that combine agricultural specialty, the integration of production and education is realized. Some activities include, for example, the creation of college students' social practice bases, the establishment of volunteer service bases, the launching of "going to the countryside" social practice activities, and innovation and entrepreneurship practice activities; and the organization of student volunteers to focus on scientific and technological support for agriculture activities, such as popularizing agricultural science knowledge, food safety advocacy, agricultural technical guidance and other activities.

\section{Implementing an Innovative Credit System to Promote General Education in the Second Classroom}

For agricultural colleges and universities, the use of second classroom for general education will help students broaden their horizons, improve their personalities, and effectively improve the quality of talent cultivation. In order to encourage students to participate in the second class, creative credit management can be introduced, where extra-curricular activities, cultural and sports activities are included in the scope of award credits. Students obtain creative credits by participating in community activities and academic competitions, studying professional works, listening to professional academic reports, publishing academic papers, and participating in scientific research projects. For example, students can participate in extracurricular activities or stylistic activities to score at a maximum of 6 credits each time. As for ideological and political education practice, credits can be combined based on credit hours, and students can be required to obtain practical credits for certain credits before graduation, with at least 2 credits for each category. Besides, in order to ensure the smooth implementation of the innovative credit system, a "faculty-college" leading group will be established to guide students' social practice activities.

\section{Improve Instructors' Assessment and Incentive System}

Teachers play an important guiding role in the implementation of the second classroom. The establishment of an incentive mechanism and assessment mechanism will help mobilize the enthusiasm of professional teachers. The work of teachers in guiding the second classroom activities should be included in the workload, and the instructors who have achieved better results should be rewarded. Because the second classroom is flexible and content-rich, colleges and universities can adopt flexible and varied assessment methods according to the actual situation.

In this paper, we referred to the accounting method of the first classroom teaching workload, and proposed a method suitable for the second classroom workload calculation. The calculation of the second classroom teacher's workload can be calculated by referring to the first classroom teaching workload calculation method. The workload of the second classroom is divided into two categories. One is training, lectures and so on. The workload of the tutor is calculated with reference to the first classroom teaching workload. Such activities need to be reported to the activity plan in advance and approved by the relevant department of the universities. The other is the organization manager of the event, such as the responsible teacher of an evening party, the tutor of a program or a competition, etc. The teacher's actual working hour is converted into a standard class hour for accounting.

\section{E. Make Good Use of the New Media Platform}

With the continuous development of new media technologies on the Internet, the Internet thinking of student 
activities in colleges and universities has become increasingly prominent, and network participation is getting higher and higher [6]. Combining traditional approaches with new media and new technologies and making full use of network resources can increase participation in activities. Firstly, the new media language is livelier than traditional media, especially with the new media language style represented by the WeChat public account. WeChat push has the characteristics of lively and vivid, and makes students happier to learn about activities through new media. Secondly, through the school's official WeChat, Weibo and other platforms, students will be able to timely understand the big events happening in the school and society, and correctly guide students' thinking and inquiry. In addition, the new media is also a good platform for teachers and students to communicate quickly, helping us to understand the second class activities and feedback from students.

\section{SUMMARY}

Paying attention to the construction of the second classroom has important practical significance for promoting the education and employment of applied colleges and universities. The second classroom construction of applied agricultural colleges and universities should be based on the characteristics of agricultural sciences. Moreover, the concept of "cultivating high quality practical talents with the spirit of serving for agriculture" should be carried into the second classroom education system. In the process of constantly exploring and improving the long-term mechanism construction of second classroom, the core competence of the university will be enhanced

\section{ACKNOWLEDGMENT}

This work was financially supported by the Tianjin Agricultural College major education reform bidding project (2017-B-00).

\section{REFERENCES}

[1] QIAO Jiang - yan, et al. A research on the educational function and mechanis $\mathrm{m}$ of the second classroom in colleges and universities, J. Changchun Inst Tech, Vol.17 pp.123-126,2016 (In Chinese)

[2] WANG Liutao, HE Dewen, "Study on the Construction of the Second Classroom Practical Teaching System of Application-oriented Undergraduate Colleges and Universities”, MEITAN HIGHE R EDUCATION, vol. 32, pp. 59-62, 2014. (In Chinese)

[3] ZENG Jianxiong, SONG Dan, GAO Shuren, "Study on the College Students' the Second Classroom: Course, Focus and Prospect---A Literature R eview Based on the CNKI Literatures from 1999 to 2016”, Chongqing Higher Education Research, vol. 5, pp. 119-127, 2017. (In Chinese)

[4] QU Fu-cun, Construction and Practice of the Second Classroom to Focus on Cultivating Students' Ability of Innovation and Entrepreneurship, EDUCATION TEACHING FORUM, vol.9, pp:4-5,2018 (In Chinese)

[5] LIN Fu-rong, Reflections upon Second Classroom Teaching and Management in Application - oriented Universities, Journal of Jilin Engineering Normal University, Vol. 34, pp:40-42,2018 (In Chinese)

[6] WANG Bo-yu, Horizon College Students Second Classroom Innovation Research Based on Internet Plus, Journal of Weinan Normal University, Vol.33,pp: 48-51, 2018 (In Chinese) 